\title{
Noise and Vibration Analysis of Conveyor Belt
}

Frantisek Klimenda, Josef Soukup, Jan Sterba

Faculty of Mechanical Engineering, J. E. Purkyne University in Usti nad Labem. Pasteurova 3334/7, 400 01 Usti nad Labem. Czech Republic. E-mail: frantisek.klimenda@ujep.cz

The article deals with the measurement of conveyor belt noise and vibration. The conveyor belt was supported on six rollers fixed on three plates of stand, return and drive drum. These six rollers were produced in two sets (convectional tube and accurate tube). Rollers were driven by a rubber belt. The noise was measured and evaluated on both sides of the conveyor. Vibration of the conveyor was measured at four locations of the conveyor construction. All measurements were performed in an unloaded condition. In conclusion of the article is a summary and evaluation of all measurements. The vibration of the conveyor is comparable in both cases, however, the rollers from accuracy tube excite the construction less, and this results in a lower total noise. By comparing the acceleration to the dominant frequency, it is obvious that the noise and the vibration of the belt conveyor construction were reduced by using rollers from accuracy tube

Keywords: Vibration, Noise, Conveyor belt

\section{Introductions}

Tube and belt conveyors are most commonly used for transporting loose and small solid materials. Like any machinery, even belt and tube conveyors are the source of noise. An important source of noise is the roller, which leads the conveyor belt. Another noise is emitted by the roller itself, the other roller, after which the belt is guided. The belt can be made of rubber, metal, textiles, etc. Therefore, it is necessary to reduce noise and hence the vibration of all parts of the conveyor.

\section{Methodology}

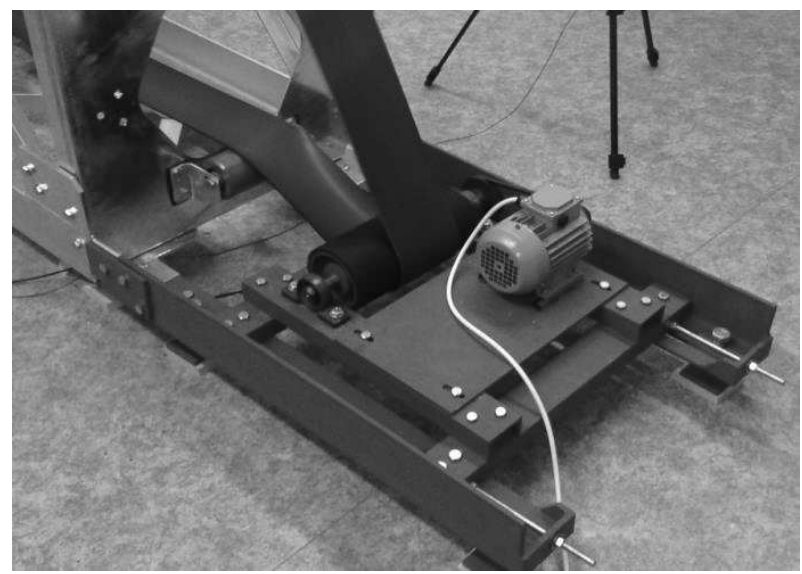

Fig. 1 Power station

Measurement of noise and vibration was carried out on the measuring stand. The measuring stand was made up of a part of the real steel construction of the tube conveyor. This stand construction consists of three main supports on which the roller holders with $\varnothing 89 \mathrm{~mm}$ and length $214 \mathrm{~mm}$ are attached. The roller has an axis of $20 \mathrm{~mm}$ in diameter. This stand was equipped by a power station (Fig. 1) and a return station (Fig. 2) and six rollers, which were driven by a rubber belt. Rubber belt is a classic composite structure of technical rubber and textile inserts. The measuring stand including the belt is shown in Fig. 3. The drive of the cylinder, at the power station, consist of an electric motor and a wedge belt transmission.

Due to the fact that a full tube conveyor was not used in the laboratory conditions, it was replaced by a flat belt. The conveyor belt is made of a conventional conveyor belt which has been cut to a width of $150 \mathrm{~mm}$, the thickness of the belt was adjusted by pulling off an excess number of textile inserts ( 2 inserts remaining). The belt has been bonded by cold gluing after installation on the bench. The rollers were always placed one at a time in the upper and lower parts of the stand. At the front upper roller a two guide rollers were placed. These rollers should possibly have prevented the belt from rolling off the rollers (the side where the liner layers were pulled off is not quite straight). During the measurement of the rotation of the guide rollers, the roller bearing in the holders did not allow a very good adjustment of the belt path.

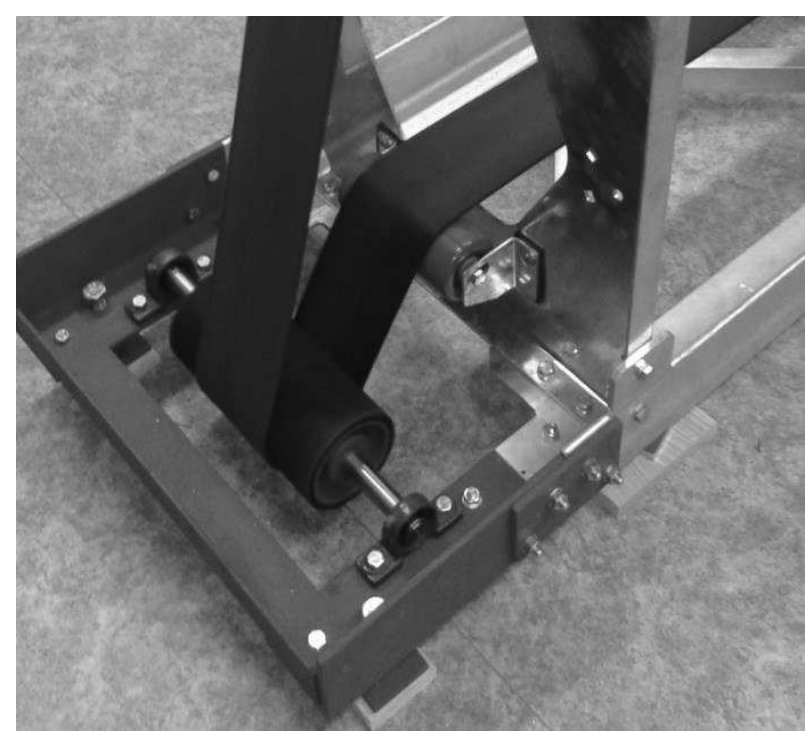

Fig. 2 Return station

The measured value was the effective acoustic pressure in $\mathrm{Pa}$, which was converted to the equivalent sound pressure level (in $\mathrm{dB}$ ) 


$$
L_{P}=10 \log \left(\frac{p_{e f}}{p_{0}}\right)^{2}=20 \log \left(\frac{p_{e f}}{p_{0}}\right)
$$

where

$p_{\text {ef }}$ - effective pressure $[\mathrm{Pa}]$,

$p_{0}$ - acoustic pressure $[\mathrm{Pa}]$.

The measurement time was $T=30 \mathrm{~s}$. The measurement of each set of rollers was done 7 times, these measurements were statistically evaluated. All noise measurements were performed with a weight filter A. Deviations due to manufacturing tolerances were expected to be measured.

Before the actual measurement, the theoretical noise level of all rollers was also analytically determined. For the calculation, the average noise level of the roller was calculated, which was converted to the noise that would

$$
L=10 \log \left(10^{\frac{L_{1}}{10}}+10^{\frac{L_{2}}{10}}+\ldots .+10^{\frac{L_{i}}{10}}\right) \quad \text { for } i=1,2,3 \ldots n,
$$

$$
L=L_{z}+10 \log n
$$

where

$L$ - resulting noise level [Pa],

$L_{i}$ - noise level of individual sources [Pa].

For $n$ same sources, the relationship is simplified to shape
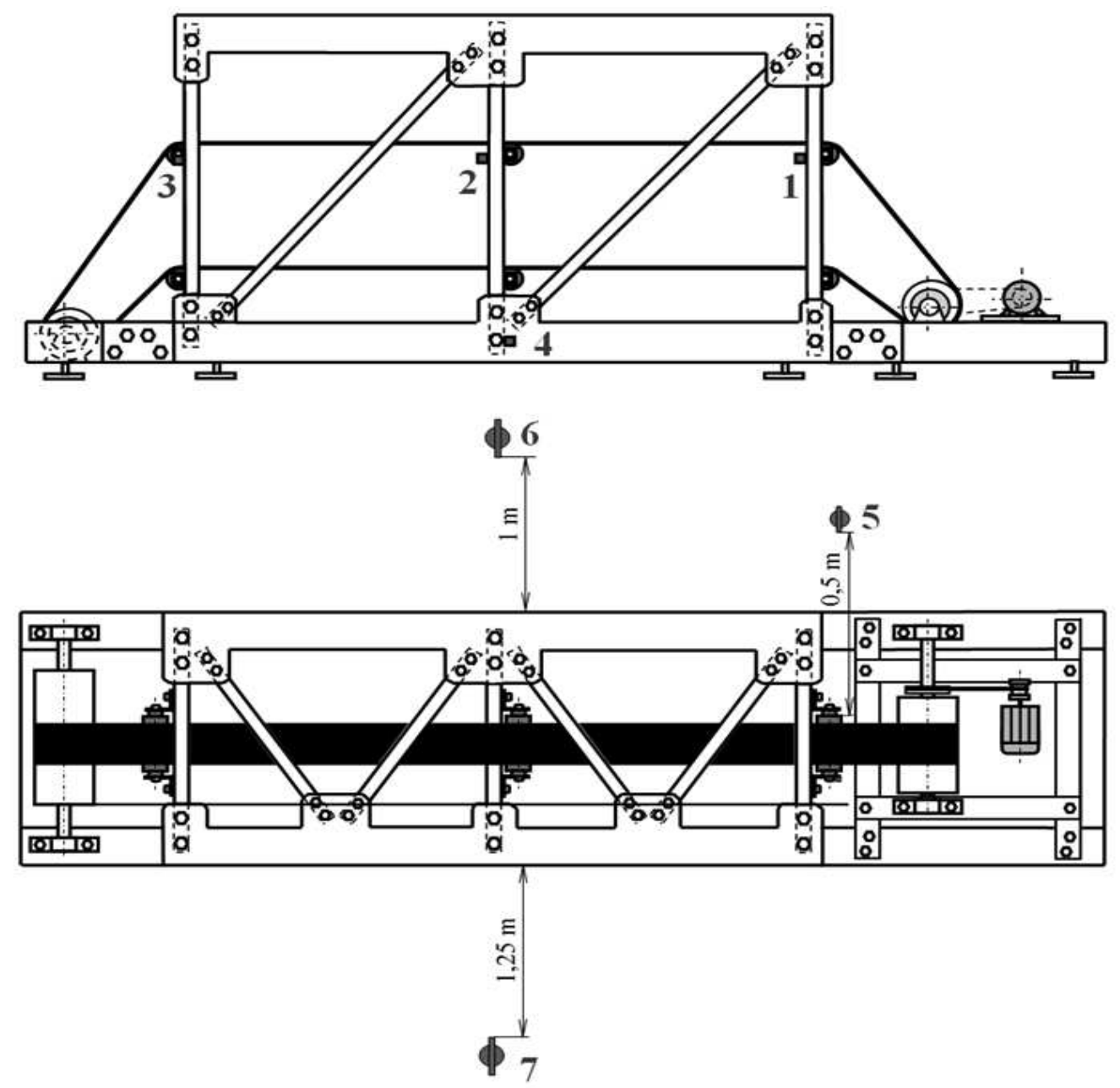

Legend: 1,2,3,4-acceleration sensors, 5 -rotation sensors, 6,7 -microphones

Fig. 4 Measurement layout 
The vibrations were measured using a three-axis piezoelectric accelerometer (type 4524-B, Brüel \& Kjær, Denmark). The vibration sensing time is the same as the noise sensing time, i.e. $T=30 \mathrm{~s}$. Accelerometers were placed on the support near the roller holder. The fourth accelerometer was placed on the lower longitudinal beam at the point of attachment of the middle support. No vibrations were measured on the auxiliary structure, i.e. on the power station and on the return station.

The acceleration and noise sensors were connected to the PULSE 3060-B-120 analyser (Brüel \& Kjær, Denmark). The location of the sensors for measurement is shown in Fig. 4.

Tab. 1 Roller Parameters $\varnothing 89 \times 214 \mathrm{~mm}$

\begin{tabular}{|c|c|c|c|l|}
\hline Serial number & $\begin{array}{c}\text { Number } \\
{[-]}\end{array}$ & $\begin{array}{c}\text { Internal designa- } \\
\text { tion }\end{array}$ & Average weight $[\mathrm{g}]$ & \multicolumn{1}{|c|}{ Note } \\
\hline 1 & 8 & $\mathrm{C} 1-\mathrm{C} 8$ & 2448.0 & $\begin{array}{l}\text { Black ring on shaft } \\
\text { Standard tube }\end{array}$ \\
\hline 2 & 8 & $\mathrm{Z} 1-\mathrm{Z} 8$ & 2542.9 & $\begin{array}{l}\text { Yellow ring on the shaft } \\
\text { Precision pipe }\end{array}$ \\
\hline
\end{tabular}

The peripheral speed of the rollers was $2.5 \mathrm{~m} . \mathrm{s}^{-1}$, which corresponds to the belt speed in operation. Measurement of noise was performed by two microphones (type 4189-A-021, Brüel \& Kjær, Denmark), located at a height of $1 \mathrm{~m}$ above the base in the middle of the stand. The microphone 1 was located $1 \mathrm{~m}$ from the stand; the microphone 2 at a distance of $1.25 \mathrm{~m}$, see Fig. 4. Meas-
The background noise when measuring the black circle rollers was $L_{P}=31.60 \mathrm{~dB}(\mathrm{~A})$, for rollers with yellow $\operatorname{ring} L_{P}=30.00 \mathrm{~dB}(\mathrm{~A})$ at $536.75 \mathrm{rpm}$, the engine speed $796.18 \mathrm{rpm}$. The belt speed was $2.5 \mathrm{~m} . \mathrm{s}^{-1}$. The roller marking, see tab. 1.

\section{Evaluation of Measurement and Discussion}

This chapter summarizes the results of measuring two sets of rollers $\varnothing 89 \times 214 \mathrm{~mm}$. Each set of rollers contained 8 rollers. One set of rollers was made of standard tube; the second set was made of precision tubes. The basic parameters of the measuring rollers used are in Tab. 1.

Tab. 2 Equivalent noise level with rollers from standard pipe ( $C$ - black ring)

\begin{tabular}{|c|c|c|c|c|c|}
\hline \multirow{2}{*}{$\begin{array}{c}\text { Measuring } \\
\text { point }\end{array}$} & \multicolumn{2}{|c|}{ Microphone 1} & \multicolumn{2}{|c|}{ Microphone 2} & \multirow{2}{*}{$\begin{array}{c}\begin{array}{c}\text { Sound meter } \\
2250 \mathrm{~L}\end{array} \\
{[\mathrm{~dB}(\mathrm{~A})]}\end{array}$} \\
\hline & $\begin{array}{c}L_{C} \\
{[\mathrm{~dB}(\mathrm{~A})]}\end{array}$ & $\begin{array}{c}L_{\text {sour }} \\
{[\mathrm{dB}(\mathrm{A})]}\end{array}$ & $\begin{array}{c}L_{C} \\
{[\mathrm{~dB}(\mathrm{~A})]}\end{array}$ & $\begin{array}{c}L_{\text {sour }} \\
{[\mathrm{dB}(\mathrm{A})]}\end{array}$ & \\
\hline $\mathrm{C} 1$ & $63.71 \pm 0.15$ & 63.70 & $63.33 \pm 0.13$ & 63.30 & \multirow{4}{*}{63.70} \\
\hline $\mathrm{C} 2$ & $63.91 \pm 0.02$ & 63.90 & $63.45 \pm 0.03$ & 63.40 & \\
\hline $\mathrm{C} 3$ & $63.97 \pm 0.04$ & 64.00 & $63.55 \pm 0.05$ & 63.50 & \\
\hline $\mathrm{C} 4$ & $64.03 \pm 0.04$ & 64.00 & $63.57 \pm 0.04$ & 63.60 & \\
\hline
\end{tabular}

Legend: sound level meter 2250-L measured in the axis of the shaft, i.e. the microphone 1 position, $L_{C}$ - total noise level (measured) $L_{\text {sour }}$ - noise source (roller) minus the background noise $L_{B}$

Tab. 3 Equivalent noise level of the belt with precision tube rollers $(Z$ - yellow ring)

\begin{tabular}{|c|c|c|c|c|c|}
\hline \multirow{2}{*}{$\begin{array}{c}\text { Measuring } \\
\text { point }\end{array}$} & \multicolumn{2}{|c|}{ Microphone 1} & \multicolumn{2}{|c|}{ Microphone 2} & \multirow{2}{*}{$\begin{array}{c}\begin{array}{c}\text { Sound meter } \\
2250 \mathrm{~L}\end{array} \\
{[\mathrm{~dB}(\mathrm{~A})]}\end{array}$} \\
\hline & $\begin{array}{c}L_{C} \\
{[\mathrm{~dB}(\mathrm{~A})]}\end{array}$ & $\begin{array}{c}L_{\text {sour }} \\
{[\mathrm{dB}(\mathrm{A})]}\end{array}$ & $\begin{array}{c}L_{C} \\
{[\mathrm{~dB}(\mathrm{~A})]}\end{array}$ & $\begin{array}{c}L_{\text {sour }} \\
{[\mathrm{dB}(\mathrm{A})]}\end{array}$ & \\
\hline $\mathrm{Z1}$ & $63.75 \pm 0.06$ & 63.70 & $62.87 \pm 0.07$ & 62.90 & \multirow{4}{*}{63.10} \\
\hline $\mathrm{Z} 2$ & $63.79 \pm 0.12$ & 63.70 & $63.39 \pm 0.08$ & 63.40 & \\
\hline $\mathrm{Z3}$ & $63.42 \pm 0.06$ & 63.40 & $62.46 \pm 0.04$ & 62.50 & \\
\hline $\mathrm{Z4}$ & $63.70 \pm 0.13$ & 63.70 & $62.86 \pm 0.17$ & 62.90 & \\
\hline
\end{tabular}

Legend: sound level meter 2250-L measured in the axis of the shaft, i.e. the microphone 1 position, $L_{C}$ - total noise level (measured) $L_{\text {sour }}$ - noise source (roller) minus the background noise $L_{B}$ 
Tab. 4 Theoretical noise of a six-roller conveyor

\begin{tabular}{|c|c|c|c|c|c|}
\hline $\begin{array}{c}\text { Roller mark- } \\
\text { ing }\end{array}$ & $\begin{array}{c}\text { Number of } \\
\text { rollers [-] }\end{array}$ & $\begin{array}{c}\text { Source noise Mi- } \\
\text { crophone 1 } \\
{[\mathrm{dB}(\mathrm{A})]}\end{array}$ & $\begin{array}{c}\text { Noise of 6 rollers } \\
{[\mathrm{dB}(\mathrm{A})]}\end{array}$ & $\begin{array}{c}\text { Source noise Mi- } \\
\text { crophone 2 } \\
{[\mathrm{dB}(\mathrm{A})]}\end{array}$ & $\begin{array}{c}\text { Noise of 6 rollers } \\
{[\mathrm{dB}(\mathrm{A})]}\end{array}$ \\
\hline $\mathrm{C}$ & 6 & 49.70 & 51.70 & 52.10 & 59.00 \\
\hline $\mathrm{Z}$ & 6 & 46.90 & 54.70 & 49.90 & 57.70 \\
\hline
\end{tabular}

Legend: $C$ - roller from a conventional tube with a black ring, $Z$ - precision tube roller with yellow ring

The results of the analytical solution of the theoretical noise of the 6-roller conveyor are shown in Tab. 4.

From the comparison of the measured values of noise (tab. 2, 3 with the values given in columns 4 and 6 of Tab. 4 ), it results that the influence of the propulsion station was relatively large in the measurement. In practice, this effect will be significantly lower, the propulsion and return stations will be far away from the conveyor sections. In reality, there will be 12 rollers on one the support, not 2 rollers as in this measurement. This will increase the noise. Both roller sets contain eight rollers. Six rollers were used from both sets $(\mathrm{C} 1-\mathrm{C} 6$ and $\mathrm{Z} 1-\mathrm{Z} 6)$ have been used, they have similar noise, differing by a maximum of $1 \mathrm{~dB}(\mathrm{~A})$.
The evaluation of acceleration and frequency of oscillations in individual measured locations is shown in Tab. 5. The first three own frequencies and the maximum amplitude of acceleration in each direction are given. All frequencies lie in the zone where the sensitivity of the human ear is high.

From tab. 5, it is obvious that individual supports have lower vibrations when using Z1 - Z6 rollers (made of precision tube). Rollers from a standard pipe, i.e. C1 - C6, have higher vibrations. These vibrations excite the steel construction of the conveyor and increase the overall noise of the device.

Fig. 5 and Fig. 6 show the acceleration and frequency magnitudes in positions 1 and 4 for both types of rollers (from standard and precision tubes) in individual axes.

Tab. 5 Vibration of construction (own frequency and size of construction acceleration)

\begin{tabular}{|c|c|c|c|c|c|c|c|c|}
\hline$\frac{\dot{0}}{\bar{\alpha}}$ & . & 芯 & $\begin{array}{l}\text { Frequency and } \\
\text { acceleration } x \\
\text { direction }\end{array}$ & & $\begin{array}{c}\text { Frequency and } \\
\text { acceleration } y \\
\text { direction }\end{array}$ & & $\begin{array}{c}\text { Frequency and } \\
\text { acceleration } z \\
\text { direction }\end{array}$ & \\
\hline & & 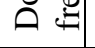 & $f_{x}[\mathrm{~Hz}]$ & $a_{x}\left[\mathrm{~m} \cdot \mathrm{s}^{-2}\right]$ & $f_{y}[\mathrm{~Hz}]$ & $a_{y}\left[\mathrm{~m} \cdot \mathrm{s}^{-2}\right]$ & $f_{z}[\mathrm{~Hz}]$ & $a_{z}\left[\mathrm{~m} \cdot \mathrm{s}^{-2}\right]$ \\
\hline \multirow{12}{*}{$\mathrm{C}$} & \multirow{3}{*}{1} & $f_{1}$ & 272 & 0.0084 & 36 & 0.0037 & 52 & 0.6727 \\
\hline & & $f_{2}$ & 72 & 0.0064 & 56 & 0.0022 & 108 & 0.3151 \\
\hline & & $f_{3}$ & 88 & 0.0050 & 92 & 0.0021 & 72 & 0.2312 \\
\hline & \multirow{3}{*}{2} & $f_{1}$ & 56 & 0.0041 & 444 & 0.0019 & 72 & 0.3447 \\
\hline & & $f_{2}$ & 141 & 0.0018 & 216 & 0.0014 & 60 & 0.1599 \\
\hline & & $f_{3}$ & 96 & 0.0016 & 276 & 0.0012 & 116 & 0.0931 \\
\hline & \multirow{3}{*}{3} & $f_{1}$ & 72 & 0.0103 & 36 & 0.0050 & 72 & 0.8330 \\
\hline & & $f_{2}$ & 56 & 0.0057 & 276 & 0.0036 & 60 & 0.2252 \\
\hline & & $f_{3}$ & 276 & 0.0009 & 96 & 0.0021 & 108 & 0.0919 \\
\hline & \multirow{3}{*}{4} & $f_{1}$ & 52 & 0.0046 & 72 & 0.0250 & 272 & 0.0126 \\
\hline & & $f_{2}$ & 44 & 0.0015 & 328 & 0.0115 & 72 & 0.0079 \\
\hline & & $f_{3}$ & 72 & 0.0009 & 208 & 0.0109 & 52 & 0.0012 \\
\hline \multirow{12}{*}{$\mathrm{Z}$} & \multirow{3}{*}{1} & $f_{1}$ & 272 & 0.0258 & 272 & 0.0115 & 48 & 0.1290 \\
\hline & & $f_{2}$ & 72 & 0.0016 & 36 & 0.0027 & 76 & 0.0951 \\
\hline & & $f_{3}$ & 60 & 0.0008 & 56 & 0.0009 & 132 & 0.0718 \\
\hline & \multirow{3}{*}{2} & $f_{1}$ & 56 & 0.0038 & 444 & 0.0022 & 72 & 0.3402 \\
\hline & & $f_{2}$ & 96 & 0.0019 & 336 & 0.0015 & 64 & 0.1617 \\
\hline & & $f_{3}$ & 524 & 0.0013 & 216 & 0.0015 & 116 & 0.1160 \\
\hline & \multirow{3}{*}{3} & $f_{1}$ & 272 & 0.0035 & 272 & 0.0068 & 60 & 0.1567 \\
\hline & & $f_{2}$ & 52 & 0.0014 & 36 & 0.0027 & 72 & 0.0765 \\
\hline & & $f_{3}$ & 72 & 0.0011 & 224 & 0.0010 & 184 & 0.0273 \\
\hline & \multirow{3}{*}{4} & $f_{1}$ & 52 & 0.0011 & 208 & 0.0094 & 272 & 0.0400 \\
\hline & & $f_{2}$ & 44 & 0.0009 & 328 & 0.0071 & 28 & 0.0012 \\
\hline & & $f_{3}$ & 292 & 0.0006 & 520 & 0.0066 & 216 & 0.0012 \\
\hline
\end{tabular}




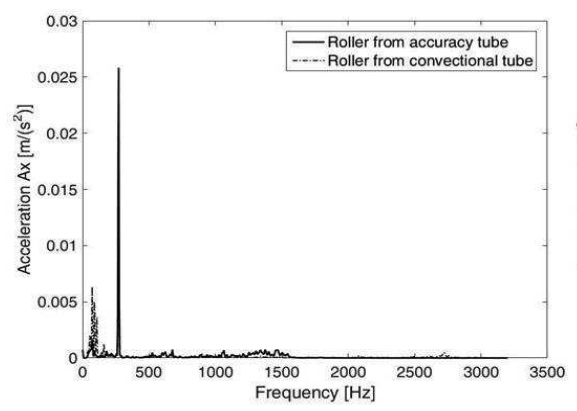

a)

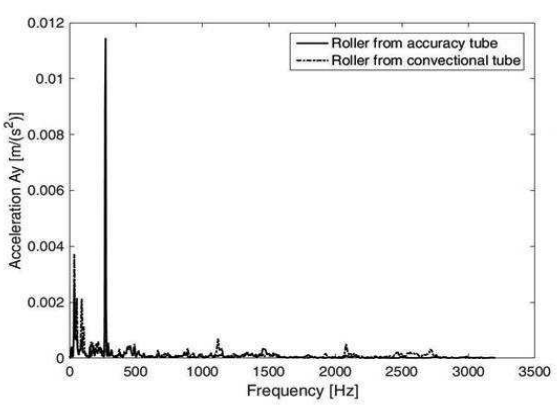

b)

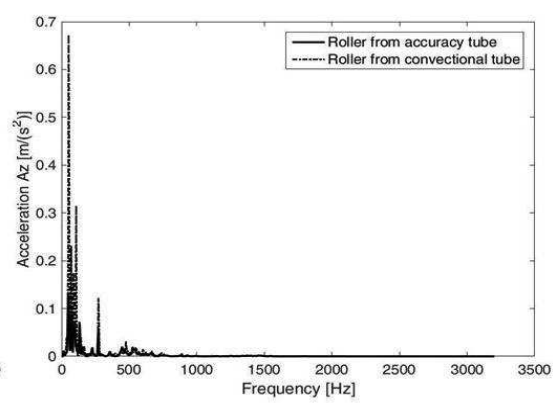

c)

Fig. 5 Frequency and magnitude of acceleration at point 1 in the $x(a), y(b)$ and $z(c)$ axes

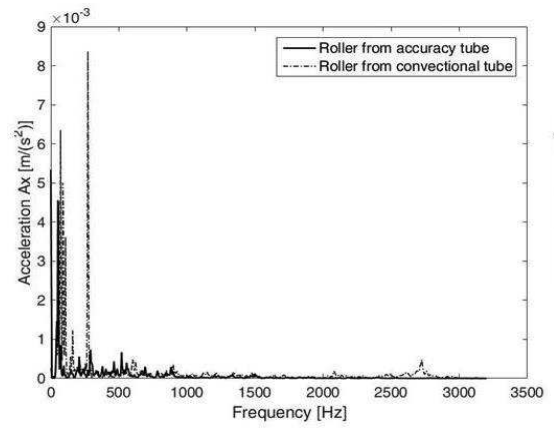

a)

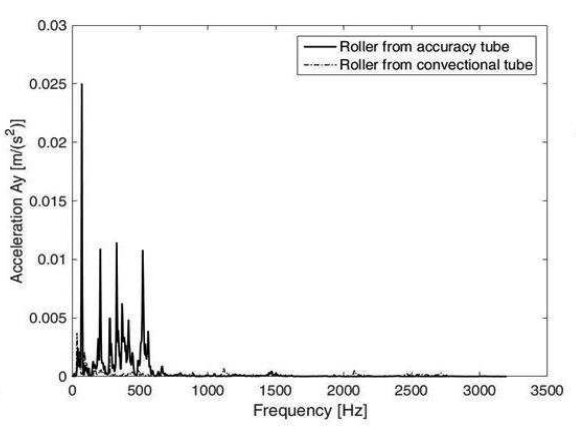

b)

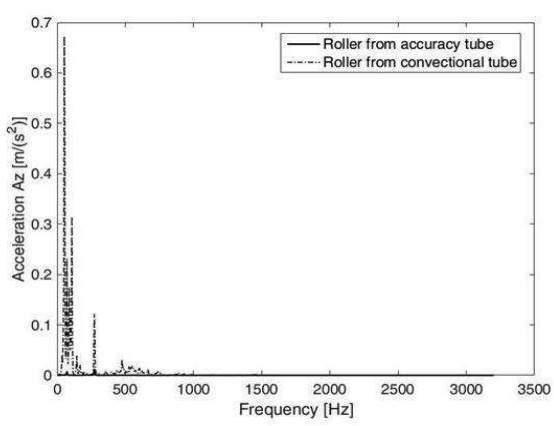

c)

Fig. 6 Frequency and magnitude of acceleration at point 4 in the $x(a), y(b)$ and $z(c)$ axes

\section{Conclusion}

The article deals with the measurement of noise and in particular the vibration of a belt conveyor driven by six rollers. These six rollers are manufactured in two versions. From the standard pipe (C1 - C6) and the precision tube $(\mathrm{Z} 1-\mathrm{Z} 6)$, the parameters of all rollers are equal $\varnothing 89$ $\times 214 \mathrm{~mm}$. The noise of the conveyor is similar to that of the two sets of rollers, with a difference of up to $3 \mathrm{~dB}(\mathrm{~A})$, which is at the accuracy of both the measurement and the accuracy in the accuracy class 2 . The vibration of the conveyor is comparable in both cases, however, the precision tube rollers blur the construction of stand less, and this results in a lower resultant noise. By comparing the acceleration to the dominant frequency, it is obvious that the noise and vibration of the belt conveyor construction were reduced by using precision tube rollers.

\section{Acknowledgement}

The research work is supported by UJEP-SGS-2018-48002-2, Czech republic.

\section{References}

[1] APETAUR, M. (2007): Acoustics of production machinery units and production areas (Akustika výrobnich strojnich celki̊ a výrobnich proctor), UJEP Ústí nad Labem, ISBN 978-80-7044-933-2

[2] NOVÝ, R. (2000): Noise and vibration (Hluk a chvěni), ČVUT Praha, ISBN 80-02246-3
[3] DIŽO, J. (2015): Evaluation of Ride Comfort for Passengers by Means of Computer Simulation, Manufacturing Technology, Vol 15, No 1, ISSN 1213-2489

[4] GERLICI, J., LACK, T., HARUČINEC, J. (2013): The Test Stand Load Modulus Implementation for the Realistic Railway Operation in the Laboratory Conditions, Manufacturing Technology, Vol 13, No 4, ISSN 1213-2489

[5] SVOBODA, M., KLIMENDA, F., KAMPO, J., SOUKUP, J. (2015): Rollers vibrafon of conveyor belt. In: 13th International Conference on Dynamical Systems - Control and Stability, Lodž, 2015, Politechnika Lodž“،, pp. 571-578, ISBN 978-83-7283-708-0

[6] BLATNICKÝ, M., DIŽO, J., BLATNICKÁ, M. (2017): Side Plate Strength Analysis of the Mechanism for Vehicle Axle Scale Calibration, Manufacturing Technology, Vol 17, No 2, ISSN 12132489

[7] LOULOVÁ, M., SUCHÁNEK, A., HARUŠINEC, J. (2017): Evaluation of the Parameters Affecting Passenger Riding Comfort of a Rail Vehicle, Manufacturing Technology, Vol 17, No 2, ISSN 1213-2489

[8] KLIMENDA, F., SKOČILASOVÁ, B., (2017): Rollers Vibration of Pipe Conveyor, Manufacturing Technology, Vol 15, No 6, ISSN 1213-2489 